\title{
Association of low levels of first trimester Pregnancy Associated Plasma Protein (PAPP-A) with adverse pregnancy outcomes: An observational study
}

\author{
Archana Ranganathan ${ }^{1 *}$, John Fresen ${ }^{2}$ and Pampa Sarkar ${ }^{3}$ \\ ${ }^{1}$ Registrar Obstetrics and Gynaecology, Oxford University Hospitals NHS Foundation Trust, John Radcliffe Hospital, Oxford, UK \\ ${ }^{2}$ Department of IT Services, University of Oxford, 13 Banbury Road, Oxford OX2 6NN, England, UK \\ ${ }^{3}$ Consultant Obstetrician and Gynaecologist, Frimley Health Foundation Trust, Wexham Park Hospital Wexham, Slough, Berkshire, UK
}

\begin{abstract}
Objectives: To explore the effects of low levels of first trimester Pregnancy Associated Plasma Protein-A (PAPP-A) on adverse pregnancy outcomes.

Design: Single centre retrospective observational study.

Setting: District general hospital.

Population: Women with singleton pregnancies with low PAPP-A, attending Heatherwood and Wexham Park Hospital for first trimester combined screening for Down syndrome.

Methods: Data was collected from Astraia Database and CMiS maternity system. Multiple linear regression models for birth weight and gestational age at delivery were developed after adjusting for confounding variables. Logistic regressions were dichotomised for preterm delivery into $<34$ weeks and $\geq 34$ weeks, birth weight centiles, into $<10^{\text {th }}$ centile and $\geq 10^{\text {th }}$ centile, and pre-eclampsia versus no pre-eclampsia.
\end{abstract}

Main outcome measures: Preterm birth, small for gestational age (SGA) and pre-eclampsia.

Results: PAPP-A levels of $\leq 0.4 \mathrm{MoM}$ is associated with SGA $<10^{\text {th }}$ centile at $\mathrm{p}=0.04$ with a positive predictive value (PPV) of $83.3 \%$ and negative predictive value (NPV) of 79.3\%. Similarly, association with preterm birth $<34$ weeks is also significant at $\mathrm{p}=0.05$ with PPV of $66 \%$ and NPV of $87.4 \%$. A significant association with pre-eclampsia $(\mathrm{p}=0.6)$ could not be identified. In our study data of PAPP-A $\leq 0.4 \mathrm{MoM}$, for every $0.1 \mathrm{MoM}$ fall in PAPP-A, there was a reduction in birth weight by $78 \mathrm{gm}$ and an earlier birth by 5.3 days.

Conclusion: There is an increased likelihood of preterm delivery and SGA with progressive reduction of PAPP-A levels below $\leq 0.4$ MoM.

\section{Introduction}

Pregnancy Associated Plasma Protein (PAPP-A) is an important glycoprotein found in maternal blood that increases as pregnancy progresses [1], although it is not specific to pregnancy [2,3]. In pregnancy, PAPP-A is principally expressed in the syncytiotrophoblast of the placenta, which forms the main source of circulating maternal PAPP-A [4-6]. PAPP-A first identified in 1974, was later shown to be a protease that cleaves insulin-like growth factor binding protein -4 and -5 (IGFBP-4 and -5) to release free Insulin-like Growth Factors (IGF-1 and IGF-2) [7-9], and known to play a critical role in the regulation of fetal and placental growth [10-12]. Insulin-like Growth Factors (IGFs) are also thought to have an important role in the autocrine and paracrine control of trophoblast invasion of the decidua [13]. Maternal serum PAPP-A concentrations reflect the placental volume; hence low levels of PAPP-A may be an indicator of impaired placental function and implantation. Reduced placental size and defective syncytiotrophoblast results in reduced secretion of PAPP-A [14,15]. The origins of fetal growth restriction, as well as pre-eclampsia, known to be associated with placental dysfunction, are reported to occur in the 1st trimester, probably due to poor placentation secondary to suboptimal trophoblastic invasion [16]. In keeping with this logic, there is emerging evidence that low PAPP-A is associated with adverse pregnancy outcomes such as pregnancy loss, preterm birth and low birth weight $[17,18]$.

Maternal serum PAPP-A levels in the first trimester are readily available in recent years due to well-established first trimester combined screening test for trisomy 21. Low PAPP-A levels are associated with an increased risk of chromosomal aberrations [19-21]. In addition to its value in predicting aneuploidy, decreased PAPP-A levels in chromosomally normal fetuses are associated with various adverse pregnancy outcomes; however not sufficiently enough to be a marker for prediction of any one outcome.

Correspondence to: Archana Ranganathan, Registrar Obstetrics and Gynaecology, Oxford University Hospitals NHS Foundation Trust, John Radcliffe Hospital, Oxford, United Kingdom, OX3 9DU, Tel: 07885406771, E-mail: rarchana123@ gmail.com

Key words: Birth weight, Fetal growth retardation, Pre-eclampsia, Pregnancy, Pregnancy-associated Plasma Protein-A, Preterm birth

Received: October 23, 2017; Accepted: November 27, 2017; Published: December 01, 2017 

study

The aim of this study was to explore and quantify the effects of low levels of first trimester PAPP-A on pregnancy outcomes, in particular Small for Gestational Age (SGA), preterm birth and development of pre-eclampsia.

\section{Methods}

This is a single centre retrospective observational study of singleton pregnancies that underwent first trimester combined screening for Down syndrome between January 2011 and December 2013 at the then Heatherwood and Wexham Park Hospitals Foundation Trust, now part of Frimley Health Foundation Trust. Pregnancy outcome data were collected until June 2014. From this cohort of women, all singleton pregnancies with PAPP-A levels $\leq 0.4 \mathrm{MoM}$ (corresponding to $5^{\text {th }}$ centile) were identified from the Astraia Obstetrics ultrasound database (www.astraia.com) with documentation and risk estimates of first trimester screening. Data regarding maternal characteristics, biomarkers, ultrasound measures and pregnancy outcomes were also collected from Astraia. This included maternal age, weight, Body Mass Index (BMI), smoking status, ethnicity, mode of conception, parity, PAPP-A in MoM, as well as outcomes including Gestational Age (GA) at delivery, mode of delivery and birth weight (live births). This information was cross-referenced with that on CMiS Maternity database (HD Clinical). CMiS database was also searched to identify any pre-existing hypertension or diabetes, subsequent development of gestational hypertension, Pre-Eclampsia (PET), or Gestational Diabetes (GDM) in these women. The birth weight centile was calculated adjusting for GA at delivery.

PAPP-A levels were measured using Thermo Fisher Scientific, Brahms Kryptor analyser. This is based on Time Resolved Amplified Cryptate Emission (TRACE) technology. Astraia converts the absolute values of PAPP-A into MoM, adjusting for fetal Crown Rump Length (CRL), maternal age, maternal weight, parity, ethnicity, smoking and use of assisted conception techniques as previously described by Kagan et al [22]. CRL and nuchal translucency (NT) measurements were assessed by trained sonographers according to guidelines outlined by Fetal Medicine Foundation [23,24] and FASP (Fetal Anomaly Screening Programme). GA was calculated from first trimester CRL.

Miscarriage was defined as fetal loss prior to 24 weeks of gestation. Preterm birth was defined as birth before 37 completed weeks of gestation (and after 24 weeks of gestation), which could be either iatrogenic or due to spontaneous preterm labour, and early preterm birth defined as that before 34 weeks of gestation. Pre-eclampsia was defined, according to the guidelines of the International Society for the Study of Hypertension in Pregnancy [25], as the occurrence of gestational hypertension with proteinuria of $300 \mathrm{mg}$ or more in $24 \mathrm{hrs}$ or two readings of elevated blood pressure and at least $2+$ on the urine dipstick analysis $6 \mathrm{hrs}$ apart. SGA was defined as a birth weight below the $10^{\text {th }}$ centile for gestational age [26].

\section{Statistical analyses}

Statistical analyses were performed using the $\mathrm{R}$ software for statistical computing and graphics, version 3.2.1. Histograms and bar charts of the variables were examined to understand the distribution of the data, and consider the possible need for transformation, to check for outliers and influential observations, and to identify sparse categories that may require recoding. A scatter plot matrix of the continuous variables was drawn to determine rough linear or nonlinear relationships in the data. The continuous variables included age, body mass index (BMI), PAPP-A, Gestational Age (GA) at delivery and birth weight. All the above variables except PAPP-A were approximately normally distributed; the distribution GA at birth is skewed to the left. Due to experimental conditions, PAPP-A formed the left tail of normal distribution. Boxplots and violin plots were drawn for the categorical/discrete predictors, which included preeclampsia, gestational diabetes, parity, smoking status and ethnicity. Bivariate analyses were performed to explore important predictors for each of our primary outcomes. The data were analysed using both linear regression (with gestational age at delivery and birth weight as continuous variables) and logistic regressions dichotomised for preterm delivery into $<34$ weeks, SGA dichotomised for $<10^{\text {th }}$ centile, and pre-eclampsia versus no pre-eclampsia. Multiple linear regression models for birth weight and gestational age at delivery were developed adjusting for confounding variables. The performances of the different models were evaluated by Receiver Operating Characteristic (ROC) curve analysis with estimation of areas under the curve (AUROC). The quality-of-fit of models was assessed using $\mathrm{r}^{2}$ and AIC (Akaike Information Criterion) [27]. Specificity, sensitivity, and predictive values were obtained for the logistic regression models. In all regression models, we used LARS (Least Angle Regression) using the lasso option, to select the variables. We considered a $\mathrm{p}$ value $<0.05$ as significant, adjusted using the Bonferroni correction for simultaneous inference.

\section{Results}

A total of 17,215 women were booked during the study period and 13,662 women underwent first trimester combined screening for trisomy 21. A total of 492 singleton pregnancies were identified with PAPP-A levels $\leq 0.4 \mathrm{MoM}$. We excluded 19 women who had spontaneous miscarriage before 14 weeks of gestation, 7 pregnancies that were terminated ( 4 for Trisomy 21, 2 for trisomy 18, and one for preterm rupture of membranes at 20 weeks) and 32 women delivered elsewhere and were considered lost to follow up. We did not impute 16 women who had missing data considering the excess of imputation required. The data from the remaining 418 women with low PAPP-A were analysed. The data is available in an anonymised form and is stored in an encrypted excel spreadsheet with the authors.

Tables S1 and S2 summarises the characteristics and outcomes of the study group are available online as supporting information. $94(22.4 \%)$ babies were born SGA $\left(<10^{\text {th }}\right.$ centile) amongst which 59 $(14.1 \%)$ were $<5^{\text {th }}$ centile. There were $54(12.9 \%)$ preterm births (GA $<37$ weeks) of which $16(3.8 \%)$ were early preterm births (GA $<34$ weeks). Multiple linear regression models and logistic regression models for birth weight and GA at delivery were drawn (Tables 1 and 2). In linear regression models, PAPP-A was found to be a significant predictive factor for birth weight ( $\mathrm{p}=0.01)$, and GA at delivery $(\mathrm{p}=0.02)$. The logistic regression model of SGA $<10$ th centile and early preterm births ( $<34$ weeks) demonstrated statistically significant association with PAPP-A at $\mathrm{p}=0.041$ and $\mathrm{p}=0.05$ respectively.

Sensitivity, specificity, predictive values and area under the curve (AUC) of the logistic regression models are shown in Table 3. Figures $1 \mathrm{a}$ and $1 \mathrm{~b}$ portray the estimated probability due to the fitted model. Figure 1a reflects the probability of SGA in terms of PAPP-A and GA at birth applied to each data point. Figure $1 \mathrm{~b}$ illustrates how the probability changes for all values of PAPP-A and GA at birth. Figure S1 in supporting information shows the ROC and area under the curve for PAPP-A MoMs with early preterm birth and SGA $<10^{\text {th }}$ centile. 


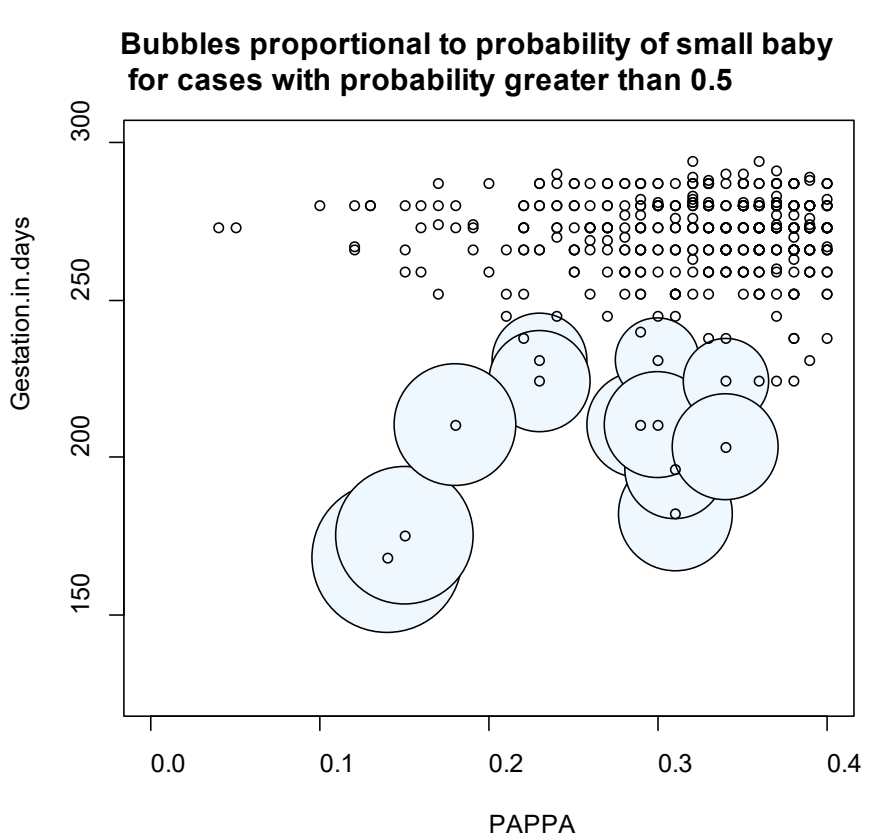

Figure 1a. is a bubble plot of probability of SGA $(<10$ th centile) on PAPP-A level(MoM) The bigger the bubble, greater is the probability of SGA. As PAPP-A levels drop, the probability of SGA increases.

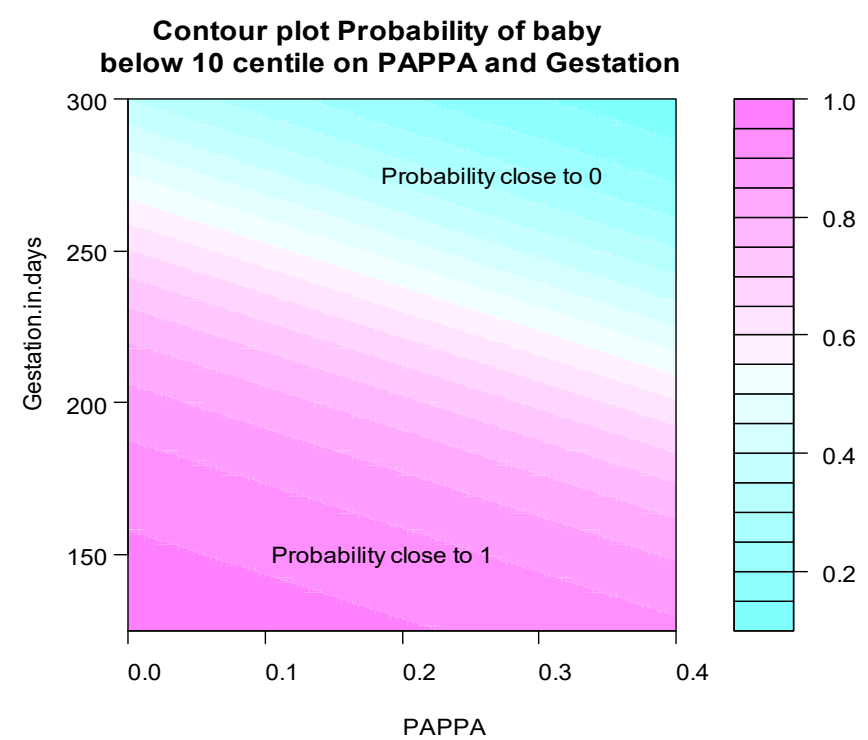

Figure 1b. is a contour plot of probability of SGA on PAPP-A level (MoM)and gestational age at delivery (in days).

\section{Discussion}

\section{Main findings}

In this study, we have demonstrated that low maternal circulating concentration of PAPP-A at 11-14 weeks of gestation significantly predicts adverse perinatal outcomes for SGA and preterm birth. We have considered the evidence available on the effect of PAPP-A on each of our primary outcomes.

In the multiple linear regression model for birth weight, PAPP-A was a highly significant predictive factor at $\mathrm{p}=0.01$ after adjusting for confounding factors namely, GA at delivery, gestational diabetes, ethnicity, pre-eclampsia, parity and smoking status (Table 1). For our data, in which PAPP-A was less than 0.4MoM, it was found that for each 0.1 MoM reduction in PAPP-A, the expected decrease in birth weight was $78 \mathrm{gm}$. The adjusted $\mathrm{r}^{2}$ for this model was $60 \%$.

Multivariate logistic regression model demonstrate that PAPP-A is associated with high probability $(\mathrm{p}=0.04)$ of SGA $<10$ th centile (Table 1). Review of the literature on the effects of PAPP-A on SGA and preterm birth is more conflicting. Some early studies did not demonstrate significant association of PAPP-A with SGA $[28,29]$ or preterm birth [29-32] whereas others showed strong association with SGA but not preterm birth [30-32]. However, more recently, larger studies have shown a significant association between PAPPA-A and SGA [17,33-36], preterm birth <37 weeks [17,34,36-39] and early preterm birth $<34$ weeks [33,34,37-40]. However, this association does not translate to prediction. On the contrary, in some studies PAPP-A has been shown to be a poor predictive factor for SGA. In the FASTER trial, PAPP-A had a positive predictive value of only $18.7 \%$ with a sensitivity of $10.4 \%$ and a negative predictive value of $91.3 \%$ for small for gestational age $\left(<10^{\text {th }}\right.$ percentile) [17]. Pihl et al. [41] inferred that it is possible to detect fetuses being SGA at delivery with a Detection Rate (DR) of only 39\% for a False Positive Rate (FPR) of 10\% using the combination of PAPP-A with other biochemical markers such as $\beta \mathrm{hCG}$ and ADAM12.

The dependence of GA at delivery on PAPP-A levels was statistically significant $(\mathrm{p}=0.026)$ in a linear model (Table 2) after adjusting Table 1. Models for birth weight

\begin{tabular}{|c|c|c|c|}
\hline \multicolumn{4}{|c|}{ Multiple linear regression model for birth weight } \\
\hline $\begin{array}{l}\text { Variables } \\
\text { (Intercept) }\end{array}$ & $\begin{array}{c}\text { Standard Error } \\
346.70\end{array}$ & $\begin{array}{l}\mathrm{t} \text {-value } \\
-14.23\end{array}$ & $\begin{array}{c}\text { p-value } \\
<2 \mathrm{e}-16^{* *}\end{array}$ \\
\hline PAPP-A & 305.24 & 2.55 & $0.01 *$ \\
\hline GA at delivery & 8.91 & 22.21 & $<2 \mathrm{e}-16^{* * *}$ \\
\hline Gestational Diabetes & 64.06 & 2.30 & 0.02 \\
\hline Parity & 43.59 & 4.11 & $4.7 \mathrm{e}-05$ \\
\hline Ethnicity & 43.33 & -3.78 & 0.0001 \\
\hline \multicolumn{4}{|c|}{ Adjusted $\mathrm{r} 2=60 \%$} \\
\hline \multicolumn{4}{|c|}{ Logistic regression model for birth weight $<10^{\text {th }}$ centile } \\
\hline $\begin{array}{l}\text { Variables } \\
\text { (Intercept) }\end{array}$ & $\begin{array}{c}\text { Standard Error } \\
1.93\end{array}$ & $\begin{array}{c}\text { t-value } \\
3.63\end{array}$ & $\begin{array}{l}\text { p-value } \\
0.00027\end{array}$ \\
\hline PAPP-A & 1.72 & -2.04 & $0.041^{*}$ \\
\hline GA at delivery & 0.007 & -3.66 & $0.0002 * *$ \\
\hline Parity & 0.24 & -1.66 & 0.09 \\
\hline Smoking & 0.32 & 1.66 & 0.96 \\
\hline
\end{tabular}

*PAPP-A is significantly associated with birth weight. ***Gestational age at delivery is highly significant in this model.

Table 2. Models for Gestational age (GA) at delivery

\begin{tabular}{|c|c|c|c|}
\hline \multicolumn{4}{|c|}{ Multiple linear regression model for GA at delivery } \\
\hline $\begin{array}{l}\text { Variables } \\
\text { (Intercept) }\end{array}$ & $\begin{array}{c}\text { Standard Error } \\
0.55\end{array}$ & $\begin{array}{c}\text { t-value } \\
67.66\end{array}$ & $\begin{array}{c}\text { p-value } \\
<2 \mathrm{e}-16^{* *}\end{array}$ \\
\hline PAPP-A & 1.68 & 2.22 & $0.02 *$ \\
\hline Mode of conception & 0.53 & -2.55 & 0.01 \\
\hline Gestational Diabetes & 0.35 & -2.45 & 0.01 \\
\hline Pre-eclampsia & 0.32 & -3.32 & 0.0009 \\
\hline \multicolumn{4}{|c|}{ Adjusted $\mathrm{r}^{2}=6.12 \%$} \\
\hline \multicolumn{4}{|c|}{ Logistic regression model for GA at delivery $<34$ weeks } \\
\hline $\begin{array}{l}\text { Variables } \\
\text { (Intercept) }\end{array}$ & $\begin{array}{c}\text { Standard Error } \\
0.96\end{array}$ & $\begin{array}{c}\text { t-value } \\
-1.61\end{array}$ & $\begin{array}{c}\mathrm{p} \text {-value } \\
0.10\end{array}$ \\
\hline PAPP-A & 3.16 & -1.95 & $0.05^{*}$ \\
\hline Pre-eclampsia & 0.56 & 1.87 & 0.06 \\
\hline
\end{tabular}

**The model is highly significant. *PAPP-A significant in both models. Pre-eclampsia, maternal diabetes and mode of conception also influence GA at delivery. 

study

Table 3. Prediction of pregnancy outcomes by low PAPP-A

\begin{tabular}{|l|c|c|c|c|c|}
\hline & Sensitivity & Specificity & $\begin{array}{c}\text { Positive } \\
\text { predictive } \\
\text { value }\end{array}$ & $\begin{array}{c}\text { Negative } \\
\text { predictive } \\
\text { value }\end{array}$ & AUC \\
\hline Preterm birth $<34$ weeks & $3.7 \%$ & $99.7 \%$ & $66 \%$ & $87.4 \%$ & 0.58 \\
\hline Birth weight $<10^{\text {th }}$ centile & $10 \%$ & $99.4 \%$ & $83.3 \%$ & $79.3 \%$ & 0.59 \\
\hline
\end{tabular}

for gestational diabetes, pre-eclampsia, and mode of conception. Maternal age and smoking status were not statistically significant and were removed from this model. Although the model was statistically significant, the adjusted $\mathrm{r}^{2}$ was $6.12 \%$. For every fall in PAPP-A by 0.1 MoM, the GA at delivery decreases by 5.3 days. However, when the same model was adjusted for birth weight, the significance of the effect of PAPP-A on gestational age at birth dropped to $\mathrm{p}=0.9$, although the model was highly statistically significant with an adjusted $\mathrm{r}^{2}$ was $59 \%$. We infer that, given that PAPP-A has significant effect on birth weight, there is interplay of relationships between PAPP-A, birth weight and GA at delivery. All three factors are strongly interlinked, and it is not possible to draw meaningful conclusions upon adjusting effects on each other.

We then constructed a multivariate logistic regression model dichotomised for preterm births $<34$ and $<37$ weeks. We found that the effect of PAPP-A was significant $(\mathrm{p}=0.05)$ for preterm births $<34$ weeks but not $<37$ weeks. Hence it appears that low PAPP-A is associated with early preterm birth. The logistic regression model for preterm births $<34$ weeks on PAPP-A, pre-eclampsia and mode of conception is demonstrated in Table 2 . There is conflicting evidence on the predictive value of PAPP-A on preterm delivery depending on the models used in the studies. For example, Beta et al. [40] observed that for prediction of spontaneous early preterm delivery, the detection rate achieved by maternal characteristics and obstetric history was not significantly improved by addition of PAPP-A MoM. Stout et al. [38] stated that for early preterm birth, in prediction models using placental protein 13 (PP-13), mean uterine artery PI (UtA-PI), maternal characteristics either alone or in combination, inclusion of PAPP-A only slightly improved the predictive utility of the models. Other earlier studies of PAPP-A and preterm delivery have found relatively low predictive values for this measure $[17,42,43]$.

We also examined the effects of low levels of PAPP-A in the development of pre-eclampsia in our study population by creating a logistic regression model using parity, BMI, extremes of maternal age, mode of conception, ethnicity (i.e. age $<20$ and $>40$ years). PAPP-A was not statistically significant in the model but raised $\mathrm{BMI}$ and nulliparity were highly significant.

Ong et al. [30] in 2000 demonstrated low maternal serum PAPP-A at 10-14 weeks of gestation in pregnancy-induced hypertension. In subsequent studies, combinations of biochemical markers and sonographic markers along with PAPP-A have been studied. Although some studies have suggested an association between PAPP-A and the subsequent risk of pre-eclampsia [18,32,43-46], Scazzochio et al.[47] found the association of PAPP-A with pre-eclampsia to be weak and became non-significant when combined with free-HCG at 8-12 weeks, blood pressure and UtA-PI at 11.0-13.6 weeks. Additionally, Poon et al. [48] reported that PAPP-A did not contribute much to the prediction of late pre-eclampsia, even when combined with maternal factors, uterine artery PI and mean arterial pressure (MAP) [48]. Foidart et al. [49] showed that PAPP-A levels significantly dropped in early not late pre-eclampsia. Despite this, the detection rate of early pre-eclampsia did not improve with the addition of PAPP-A to UtA-PI and sEng (soluble endoglin) to the analysis. Giguere et al. [50] observed that the combination of two clinical characteristics and four biochemical markers (sFlt-1, PlGF, PAPP-A and inhibin A) could not out-perform a logistic model using two clinical characteristics alone, namely prepregnancy BMI and MAP at first prenatal visit. Recently, Wright et al. [51] reported the detection rate of preterm pre-eclampsia marginally improved from $45 \%$ with maternal characteristics to $51 \%$ with PAPP-A. Current evidence indicates that PAPP-A as a one-time single marker test for prediction of pre-eclampsia has limited value [43].

We consider the strengths in our study to include that all women had pregnancy dated accurately in the $1^{\text {st }}$ trimester, calculated consistently by CRL between 11 and $13+6$ weeks. Secondly, the levels of serum markers did not influence clinical management. Our population was of multi-ethnic origin and this enables generalisation of findings. We used a robust statistical approach to design a linear regression model to determine the association of PAPP-A with the primary outcome measures, after adjusting for important covariates such as smoking status, maternal age that could be influential. Our study results are in close agreement with the observations made by several other studies, and in addition to this, it also provides an estimate of the effect size of PAPP-A level on birth weight and gestational age at delivery. To our knowledge this is the first study to measure the quantitative effect of PAPP-A on birth weight and GA at delivery.

\section{Limitations}

The study is not without limitations, including the small sample size and small range of PAPP-A values of $\leq 0.4 \mathrm{MoM}$ has limited our ability to detect its full range of effects, and that the number of pregnancies that developed pre-eclampsia were small.

\section{Conclusion}

The association of PAPP-A levels $\leq 0.4 \mathrm{MoM}$ with SGA and early preterm birth is statistically significant. However, a significant association with pre-eclampsia was not identified. The likelihood of an adverse outcome increases as the PAPP-A level decreases, but it is not sufficiently predictive to be used clinically on its own.

Given the inter-dependence of PAPP-A, GA at delivery and birth weight, perhaps future research methodology should include structural equation models of these variables, which may give a more realistic approximation to the process.

\section{Acknowledgements}

Ms Joanne Bastin, Senior Sonographer ran the search in Astraia database.

\section{Authorship and Contributor ship}

PS and AR conceived and designed the study. AR collected the data and along with JF analysed the data. JF, AR and PS were involved with interpretation of the results. AR wrote the manuscript, JF and PS commented on and contributed to the revision of drafts and final version of the article.

\section{Details of Ethics Approval}

This study was registered with the Department of clinical audit at Heatherwood and Wexham Park Hospital and received approval to retrieve information from electronic records (CMiS and Astraia). The procedures used were in accordance with the guidelines of the Helsinki Declaration on Human Experimentation and the Good Clinical Practice (CGP) guidelines. 

study

\section{References}

1. Lin T, Halbert S, Kiefer D, Spellacy W (1974) Three pregnancy-associated human plasma proteins: purification, monospecific antisera and immunological identification. Int Arch Allergy 47: 35-53.

2. Bischof P, Martin-du-Pan R, Lauber K, Girard J, Herrmann W, et al. (1983) Human Seminal Plasma Contains a Protein that Shares Physicochemical, Immunochemical, and Immunosuppressive Properties with Pregnancy-Associated Plasma Protein-A. J Clin Endocrinol Metab 56: 359-362. [Crossref]

3. DuBerg S, Bischof P, Schindler A, Beguin F, Herrmann W, et al. (1982) Tissue and plasma concentrations of pregnancy-associated plasma protein-A (PAPP-A): comparison with other fetoplacental products. BJOG 89: 352-357.

4. Bonno M, Oxvig C, Kephart GM, Wagner JM, Kristensen T, et al. (1994) Localization of pregnancy-associated plasma protein-A and colocalization of pregnancy-associated plasma protein-A messenger ribonucleic acid and eosinophil granule major basic protein messenger ribonucleic acid in placenta. Lab Invest 71: 560-566. [Crossref]

5. Chemnitz J, Tornehave D, Teisner B, Poulsen HK, Westergaard JG (1984) The localization of pregnancy proteins (hPL, SP1 and PAPP-A) in intra- and extrauterine pregnancies. Placenta 5: 489-494. [Crossref]

6. Lin TM, Halbert SP, Spellacy WN (1974) Measurement of pregnancy-associated plasma proteins during human gestation. J Clin Invest 54: 576-582. [Crossref]

7. Lawrence JB, Oxvig C, Overgaard MT, Sottrup-Jensen L, Gleich GJ, et al. (1999) The insulin-like growth factor (IGF)-dependent IGF binding protein-4 protease secreted by human fibroblasts is pregnancy-associated plasma protein-A. Proc Natl Acad Sci U S A 96: 3149-3153. [Crossref]

8. Overgaard MT, Boldt HB, Laursen LS, Sottrup-Jensen L, Conover CA, et al. (2001) Pregnancy-associated plasma protein-A2 (PAPP-A2), a novel insulin-like growth factor-binding protein-5 proteinase. J Biol Chem 276: 21849-21853. [Crossref]

9. Laursen LS, Overgaard MT, Soe R, Boldt HB, Sottrup-Jensen L, et al. (2001) Pregnancy-associated plasma protein-A (PAPP-A) cleaves insulin-like growth factor binding protein (IGFBP)-5 independent of IGF: implications for the mechanism of IGFBP-4 proteolysis by PAPP-A. FEBS Lett 504: 36-40. [Crossref]

10. Randhawa $R$ (2008) The insulin-like growth factor system and fetal growth restrictionn. Pediatr Endocrinol Rev 6: 235-240. [Crossref]

11. Clemmons DR (1998) Role of insulin-like growth factor binding proteins in controlling IGF actions. Mol Cell Endocrinol 140: 19-24. [Crossref]

12. van Kleffens M, Groffen C, Lindenbergh-Kortleve DJ, van Neck JW, Gonzalez-Parra S, et al. (1998) The IGF system during fetal-placental development of the mouse. Mol Cell Endocrinol 140: 129-136. [Crossref]

13. Irwin JC, Suen LF, Martina NA, Mark SP, Giudice LC (1999) Role of the IGF system in trophoblast invasion and pre-eclampsia. Hum Reprod 2: 90-96. [Crossref]

14. Odibo AO, Patel KR, Spitalnik A, Odibo L, Huettner P (2014) Placental pathology, first-trimester biomarkers and adverse pregnancy outcomes. J Perinatol 34: 186-191. [Crossref]

15. Costa SL, Proctor L, Dodd JM, Toal M, Okun N, et al. (2008) Screening for placental insufficiency in high-risk pregnancies: is earlier better? Placenta 29: 1034-1040. [Crossref]

16. Khong T, De Wolf F, Robertson W, Brosens I (1987) Inadequate maternal vascular response to placentation in pregnancies complicated by preeclampsia and by small-forgestational age infants. Br J Obstet Gynaecol 42: 503-505. [Crossref]

17. Dugoff L, Hobbins JC, Malone FD, Porter TF, Luthy D, et al. (2004) First-trimester maternal serum PAPP-A and free-beta subunit human chorionic gonadotropin concentrations and nuchal translucency are associated with obstetric complications: a population-based screening study (the FASTER Trial). Am J Obstet Gynecol 191:144651. [Crossref]

18. Ong CY, Liao AW, Spencer K, Munim S, Nicolaides KH (2000) First trimester materna serum free $B$ human chorionic gonadotrophin and pregnancy associated plasma protein A as predictors of pregnancy complications. BJOG 107: 1265-1270. [Crossref]

19. Brambati B, Macintosh M, Teisner B, Maguiness S, Shrimanker K, et al. (1993) Low maternal serum levels of pregnancy associated plasma protein A (PAPP-A) in the firs trimester in association with abnormal fetal karyotype. BJOG 100: 324-326. [Crossref]

20. Brizot ML, Snijders R, Bersinger NA, Kuhn P, Nicolaides KH (1994) Maternal serum pregnancy-associated plasma protein A and fetal nuchal translucency thickness for the prediction of fetal trisomies in early pregnancy. Obstet Gynecol 84: 918-922. [Crossref]
21. Zimmermann R, Hucha A, Savoldelli G, Binkert F, Achermann J, et al. (1996) Serum parameters and nuchal translucency in first trimester screening for fetal chromosomal abnormalities. Br J Obstet Gynaecol 103: 1009-1014. [Crossref]

22. Kagan K, Wright D, Spencer K, Molina F, Nicolaides K (2008) First-trimester screening for trisomy 21 by free beta-human chorionic gonadotropin and pregnancy-associated plasma protein-A: impact of maternal and pregnancy characteristics. Ultrasound Obstet Gynecol 31: 493-502. [Crossref]

23. Nicolaides K, Brizot M, Snijders R (1994) Fetal nuchal translucency: ultrasound screening for fetal trisomy in the first trimester of pregnancy. Br J Obstet Gynaecol 101: 782-786. [Crossref]

24. Snijders R, Noble P, Sebire N, Souka A, Nicolaides K (1998) UK multicentre project on assessment of risk of trisomy 21 by maternal age and fetal nuchal-translucency thickness at 10-14 weeks of gestation. Lancet 352: 343-346. [Crossref]

25. Brown MA, Lindheimer MD, de Swiet M, Assche AV, Moutquin J-M (2001) The classification and diagnosis of the hypertensive disorders of pregnancy: statement from the International Society for the Study of Hypertension in Pregnancy (ISSHP). Hypertens Pregnancy 20: ix-xiv. [Crossref]

26. Robson S C, Martin W L, Morris R K (2014) The investigation and management of the small-for-gestational-age fetus. Greentop guideline no. 31: Royal College of Obstetrics and Gynaecology, London UK. 1-33 p.

27. Efron B, Hastie T, Johnstone I, Tibshirani R (2004) Least angle regression. Ann Stat 32: 407-499.

28. Johnson MR, Riddle AF, Grudzinskas JG, Sharma V, Collins WP, et al. (1993) Reduced circulating placental protein concentrations during the first trimester are associated with preterm labour and low birth weight. Hum Reprod 8: 1942-1947. [Crossref]

29. Morssink LP, Kornman LH, Hallahan TW, Kloosterman MD, Beekhuis JR, et al. (1998) Maternal serum levels of free beta-hCG and PAPP-A in the first trimester of pregnancy are not associated with subsequent fetal growth retardation or preterm delivery. Prenat Diagn 18: 147-52. [Crossref]

30. Ong CY, Liao AW, Spencer K, Munim S, Nicolaides KH (2000) First trimeste maternal serum free beta human chorionic gonadotrophin and pregnancy associated plasma protein A as predictors of pregnancy complications. BJOG 107: 1265-1270. [Crossref]

31. Tul N, Pusenjak S, Osredkar J, Spencer K, Novak-Antolic Z (2003) Predicting complications of pregnancy with first-trimester maternal serum free-betahCG, PAPP-A and inhibin-A. Prenat Diagn 23: 990-996. [Crossref]

32. Yaron Y, Heifetz S, Ochshorn Y, Lehavi O, Orr-Urtreger A (2002) Decreased first trimester PAPP-A is a predictor of adverse pregnancy outcome. Prenat Diagn 22: 778782. [Crossref]

33. Krantz D, Goetzl L, Simpson JL, Thom E, Zachary J, et al. (2004) Association of extreme first-trimester free human chorionic gonadotropin-beta, pregnancy-associated plasma protein $\mathrm{A}$, and nuchal translucency with intrauterine growth restriction and other adverse pregnancy outcomes. Am J Obstet Gynecol 191: 1452-1458. [Crossref]

34. Smith GC, Stenhouse EJ, Crossley JA, Aitken DA, Cameron AD, et al. (2002) Early pregnancy levels of pregnancy-associated plasma protein a and the risk of intrauterine growth restriction, premature birth, preeclampsia, and stillbirth. J Clin Endocrinol Metab 87: 1762-1767. [Crossref]

35. Spencer K, Cowans NJ, Avgidou K, Molina F, Nicolaides KH (2008) First-trimeste biochemical markers of aneuploidy and the prediction of small-for-gestational age fetuses. Ultrasound Obstet Gynecol 31: 15-19. [Crossref]

36. Dane B, Dane C, Kiray M, Cetin A, Koldas M, et al. (2010) Correlation between firsttrimester maternal serum markers, second-trimester uterine artery doppler indices and pregnancy outcome. Gynecol Obstet Invest 70: 126-131. [Crossref]

37. Spencer K, Cowans NJ, Molina F, Kagan KO, Nicolaides KH (2008) First-trimeste ultrasound and biochemical markers of aneuploidy and the prediction of preterm or early preterm delivery. Ultrasound Obstet Gynecol 31: 147-152. [Crossref]

38. Stout MJ, Goetzinger KR, Tuuli MG, Cahill AG, Macones GA, et al. (2013) First trimester serum analytes, maternal characteristics and ultrasound markers to predict pregnancies at risk for preterm birth. Placenta 34: 14-19. [Crossref]

39. Kirkegaard I, Uldbjerg N, Petersen OB, Torring N, Henriksen TB (2010) PAPP-A, free beta-hCG, and early fetal growth identify two pathways leading to preterm delivery. Prenat Diagn 30: 956-963. [Crossref]

40. Beta J, Akolekar R, Ventura W, Syngelaki A, Nicolaides KH (2011) Prediction of spontaneous preterm delivery from maternal factors, obstetric history and placenta perfusion and function at 11-13 weeks. Prenat Diagn 31: 75-83. [Crossref] 

study

41. Pihl K, Larsen T, Krebs L, Christiansen M (2008) First trimester maternal serum PAPP-A, beta-hCG and ADAM12 in prediction of small-for-gestational-age fetuses. Prenat Diagn 28: 1131-1135. [Crossref]

42. Krantz D, Goetzl L, Simpson JL, Thom E, Zachary J, et al. (2004) Association of extreme first-trimester free human chorionic gonadotropin- $\beta$, pregnancy-associated plasma protein $\mathrm{A}$, and nuchal translucency with intrauterine growth restriction and other adverse pregnancy outcomes. Am J Obstet Gynecol 191: 1452-1458. [Crossref]

43. Spencer CA, Allen VM, Flowerdew G, Dooley K, Dodds L (2008) Low levels of maternal serum PAPP-A in early pregnancy and the risk of adverse outcomes. Prenat Diagn 28: 1029-1036. [Crossref]

44. Odibo AO, Zhong Y, Goetzinger KR, Odibo L, Bick JL, et al. (2011) First-trimester placental protein 13, PAPP-A, uterine artery Doppler and maternal characteristics in the prediction of pre-eclampsia. Placenta 32: 598-602. [Crossref]

45. Poon LC, Maiz N, Valencia C, Plasencia W, Nicolaides KH (2009) First-trimester maternal serum pregnancy-associated plasma protein-A and pre-eclampsia. Ultrasound Obstet Gynecol 33: 23-33. [Crossref]
46. Smith GCS, Stenhouse EJ, Crossley JA, Aitken DA, Cameron AD, et al. (2002) Early Pregnancy Levels of Pregnancy-Associated Plasma Protein A and the Risk of Intrauterine Growth Restriction, Premature Birth, Preeclampsia, and Stillbirth. J Clin Endocrinol Metab 87: 1762-1767. [Crossref]

47. Scazzocchio E, Figueras F, Crispi F, Meler E, Masoller N, et al. (2013) Performance of a first-trimester screening of preeclampsia in a routine care low-risk setting. $\mathrm{Am} \mathrm{J}$ Obstet Gynecol 208: 203.e1-203.e10. [Crossref]

48. Poon LC, Stratieva V, Piras S, Piri S, Nicolaides KH (2010) Hypertensive disorders in pregnancy: combined screening by uterine artery Doppler, blood pressure and serum PAPP-A at 11-13 weeks. Prenat Diagn 30: 216-223. [Crossref]

49. Foidart JM, Munaut C, Chantraine F, Akolekar R, Nicolaides KH (2010) Maternal plasma soluble endoglin at 11-13 weeks' gestation in pre-eclampsia. Ultrasound Obstet Gynecol 35: 680-687. [Crossref]

50. Giguere Y, Masse J, Theriault S, Bujold E, Lafond J, et al. (2015) Screening for preeclampsia early in pregnancy: performance of a multivariable model combining clinical characteristics and biochemical markers. BJOG 122: 402-410. [Crossref]

51. Wright A, Guerra L, Pellegrino M, Wright D, Nicolaides KH (2016) Maternal serum PAPP-A and free $\hat{I}^{2}-\mathrm{hCG}$ at 12,22 and 32 weeks' gestation in screening for preeclampsia. Ultrasound Obstet Gynecol 47: 762-767. [Crossref]

Copyright: (O2017 Ranganathan A. This is an open-access article distributed under the terms of the Creative Commons Attribution License, which permits unrestricted use, distribution, and reproduction in any medium, provided the original author and source are credited. 